\title{
CHRONIC TOTAL CORONARY ARTERY OCCLUSION RECANALISATION WITH PERCUTANEOUS CORONARY INTERVENTION - SINGLE CENTRE 10-YEAR EXPERIENCE
}

\author{
Artis Kalniņš $^{1, \#}$, leva Strēle ${ }^{2}$, Irēna Kurcalte ${ }^{1,2}$ Aivars Lejnieks $^{1,2}$, and Andrejs Ërglis ${ }^{3,4}$ \\ ${ }^{1}$ Rīga East University Hospital, 2 Hipokrāta Str., Rīga, LV-1038, LATVIA \\ ${ }^{2}$ Rīga Stradiṇš University, 16 Dzirciema Str., Rīga, LATVIA \\ ${ }^{3}$ Latvian Centre of Cardiology, Pauls Stradiṇš Clinical University Hospital, 13 Pilsoṇu Str., Rīga, LV-1002, LATVIA \\ ${ }^{4}$ Faculty of Medicine, University of Latvia, 1a Šarlotes Str., Rīga, LV-1001, LATVIA \\ \# Corresponding author: artis.kalnins@aslimnica.Iv
}

Contributed by Aivars Lejnieks

\begin{abstract}
Coronary artery chronic total occlusions (CTO) are common - approximately one-third of patients with significant coronary artery disease on angiography have at least 1 CTO. Invasive treatment of these lesions still remain a major challenge for interventional cardiology due to their complexity. Historically, success rates have improved to about $60-70 \%$ by using only the traditional antegrade approach. The results have dramatically improved during the last decade after more widespread application of new retrograde techniques. The aim of our study was to review and analyse single hospital experience in CTO invasive treatment and to evaluate the long-term results. A total of 519 patients undergoing percutaneous coronary interventions (PCI) for CTO at a single tertiary $\mathrm{PCl}$ centre (Riga East University Hospital), were included in the study. The median age was 64 years (38-88), and $80 \%$ were male. The retrograde approach (RA) was used for $167(32.2 \%)$ of the CTO PCl patients. The overall patient success rate was $81.3 \%$ and it increased from $73.9 \%$ in 2007 to $95.2 \%$ in 2015 ( $\mathrm{p}<0.001$ ). Mean patient observation time was five years. Overall survival was found significantly better in patients group after successful CTO $\mathrm{PCl}$ procedures (Long-rank test, $\mathrm{p}=0.013$ ).
\end{abstract}

Key words: invasive treatment, chronic total occlusions, antegrade and retrograde approach.

\section{INTRODUCTION}

Despite developments in interventional cardiology during the last decade, chronic total occlusions (CTO) still remain as one of the unresolved problems in percutaneous coronary interventions (PCI) (Prasad et al., 2007). CTO prevalence is high; approximately one-third of patients with significant coronary artery disease on angiography has at least 1 CTO, but only less than $10 \%$ of percutaneous revascularisations are CTO interventions (Werner et al., 2009). CTO PCI is performed infrequently, likely due to historically low procedural success rates, technical complexity, high equipment use and the potential for major procedural complications (Shah, 2011). Although several studies have shown that successful recanalisation of chronic total occlusion (CTO) of the coronary arteries has been associated with improved survival, improved left ventricular systolic function, reduced angina, avoidance of coronary artery bypass grafting, and increased exercise capacity, the overall benefit of recanalisation of CTO is still limited by the deficiency of pro- spective randomised trials, properly powered for hard clinical endpoints, comparing contemporary optimal medical therapy with contemporary state of the art CTO recanalisation (Hoye et al., 2005).

The retrograde approach is a relatively novel technique of PCI for CTO, which allows the advancement of a guide wire in a coronary segment distal to occlusion through collateral vessels. In 1990, the first report of a retrograde approach for CTO was published, in which the retrograde wire crossing technique was applied via a degenerated saphenous vein graft (SVG) (Kahn et al., 1990). Later septal collaterals were considered to provide potential access for the retrograde approach. In 2005, Katoh and colleagues opened a new era of retrograde CTO recanalisation with the Controlled Antegrade and Retrograde subintimal Tracking (CART) technique (Surmely et al., 2006). Different kinds of retrograde techniques were introduced in the last years. Novel techniques hold promise in the field of percutaneous coronary intervention for CTO (Saito et al., 2008). 
The first successful retrograde PCI of CTO in Rìga East University Hospital was conducted in January 2007.

The aim of our study was to review 10-year data from a single hospital on CTO PCI experience and compare CTO PCI procedural parameters and treatment results using antegrade and/or retrograde approaches.

\section{MATERIALS AND METHODS}

The study included all patients undergoing PCI for CTO at a single tertiary PCI centre during 10 years - between January 2007 and January 2016. A total of 9564 PCI procedures were conducted in this period in our institution. 591 (6.17\%) of them were CTO PCI, which was applied for 519 patients. Ten patients had 2 coronary arteries CTOs, for 49 patients more than one CTO PCI attempt was made. The retrograde approach was used for $167(32.2 \%)$ of all CTO PCI patients.

A CTO lesion was defined as an obstruction of a coronary artery with Thrombolysis in Myocardial Infarction (TIMI) flow grade 0 with an estimated duration of at least three months. The duration of the occlusion was determined by the interval from the last episode of acute coronary syndrome consistent with the location of the occlusion or proven by previous angiography.

Indications for performing CTO PCI were at least one of the following: symptoms (angina), positive exercise test, ischemia. PCI was also performed for asymptomatic CTO patients after myocardial infarction in the non CTO area with normal ECG and normal echo findings at CTO related area.

The J-CTO score was used for CTO complexity assessment. This score is the sum of anatomical findings and previous attempt results - predictors of procedure failure: blunt stump, CTO length $>20 \mathrm{~mm}$, presence of severe calcification, proximal segment tortuosity, and previous attempt failure.

An attempt of using the retrograde approach was defined as the introduction of a guide wire into the collateral channels (CCs), which was connecting to the target CTO vessel distal to the lesion. Length of the CTO was measured following bilateral simultaneous coronary injections by visualising the filling of both proximal and distal occluded artery.

Procedural success was defined as a successful guide wire and balloon crossing with residual stenosis $<10 \%$ and Thrombolysis in Myocardial Infarction grade 3 flow.

All patients were pretreated with aspirin and clopidogrel. 5000 units of Heparin was used at the beginning of every procedure. Additional 2500 units of Heparin were injected every hour. Activated clotting time (ACT) was not measured. No GP 2B3A receptor blockers used. Both femoral punctures with 6-8 French (Fr) guiding catheter were used commonly. In some cases a radial route was performed to- gether with femoral approach. Only guiding catheters with side holes were used.

The decision and technique used to perform a retrograde attempt was based on operators discretion. If CTO lesion morphology was unfavourable (i.e., blunt stump, ostial location, side branch located exactly at the proximal cap of CTO), with expected low success rate of an antegrade approach, or in a case of unsuccessful antegrade attempt(s) to recanalise a CTO with connecting collaterals filling of the distal part of the target vessel, the retrograde approach was considered as a treatment option. The retrograde approach technique evolved over time with growing operator experience and emergence of dedicated devices.

Patients were separated according to year when PCI was performed, approach (antegrade or retrograde) and PCI results (successful or unsuccessful). Demographic and procedural data were collected at the time of intervention. Inhospital MACE (myocardial infarction, urgent revascularisation, stroke or death) was documented at discharge. Post discharge data was obtained by telephone follow up.

Statistical analysis was performed using IBM SPSS Statistics for Windows, version 22.0. Continuous variables were summarised as mean value \pm standard deviation (SD) if normally distributed or as median value and interquartile range (IQR) if data distribution was skewed. Unpaired two-sided t-test and Mann-Whitney U tests were used to compare subgroups. Categorical variables were presented as proportions and subgroups compared by a chi-square test (or chi-square test for trends if applicable). Significance of differences in overall survival between subgroups was tested by KaplanMeier method and log-rank test. A Cox proportional hazard model was used to adjust for potential confounders such as age and sex; the results of the model were presented as hazard ratio (HR) with $95 \%$ confidence intervals (CI). A $p$ value less than 0.05 was set to indicate statistically significant differences.

\section{RESULTS}

A total of 519 patients undergoing PCI for CTO were included. The median (IQR) age was 64 yrs (38-88), and $80 \%$ (415) were male. A retrograde approach (RA) was used for $167(32.2 \%)$ patients. Use of a retrograde approach (RA) increased from $13 \%$ in 2007 to $51.3 \%$ in 2013 and decreased to $40.5 \%$ in 2015 (Fig. 1, Table 1). The overall patient success rate was $81.3 \%$ and it increased from $73.9 \%$ in 2007 to $95.2 \%$ in 2015 ( $p<0.001)$ (Fig. 2).

Table 2 shows baseline demographic and angiographic characteristics of CTO patients.

The target artery with CTO lesions included the left main (two cases, $0.4 \%$ ) right coronary artery (305 cases, 58.8\%), the left anterior descending artery (167 cases, 32.17\%), and the left circumflex artery (45 cases, $8.7 \%$ ). A retrograde approach was used in 36.9\% $(\mathrm{n}=111)$ of RCA, $25.9 \%(\mathrm{n}=$ 43) of LAD and $26.7 \%$ (n 12) of LCX cases. 


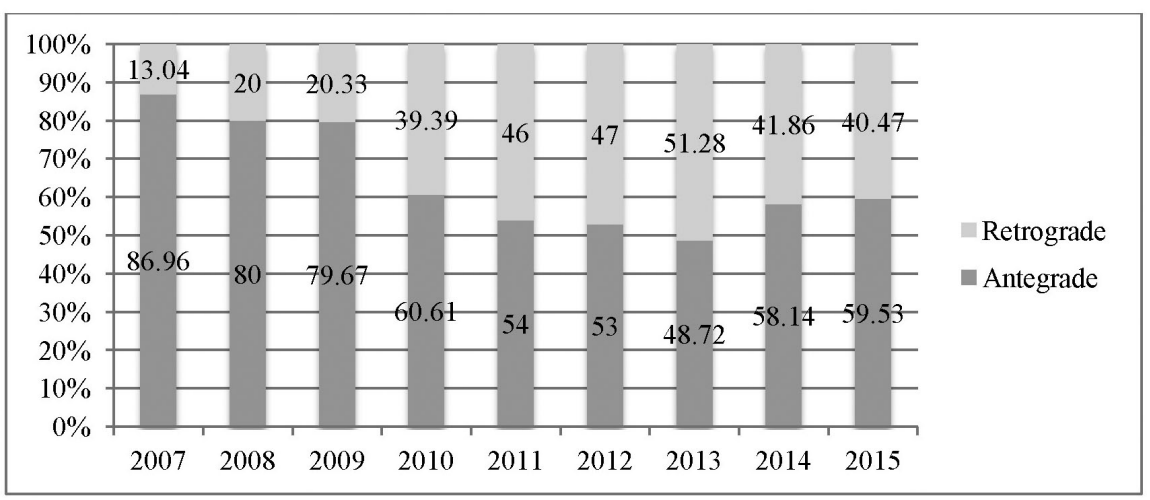

Fig. 1. Antegrade and retrograde approach usage in CTO PCI cases 2007-1015. CTO, chronic total occlusions; PCI, percutaneous coronary interventions
Table 1

NUMBER OF TOTAL AND RETROGRADE CTO PCI 2007-2015

\begin{tabular}{ccccc}
\hline Year & $\begin{array}{c}\text { Overall } \\
\text { CTO PCI }\end{array}$ & $\begin{array}{c}\text { Retrograde } \\
\text { CTO PCI }\end{array}$ & $\begin{array}{c}\text { Retrograde } \\
\text { CTO \% }\end{array}$ \\
\hline 2007 & 69 & 9 & 13.0 \\
2008 & 100 & 20 & 20.0 \\
2009 & 59 & 12 & 20.3 \\
2010 & 66 & 26 & 39.4 \\
2011 & 50 & 23 & 46.0 \\
2012 & 51 & 24 & 47.0 \\
2013 & 39 & 20 & 51.3 \\
2014 & 43 & 18 & 41.9 \\
2015 & 42 & 17 & 40.5 \\
Total & 519 & 167 & 32.2 \\
\hline
\end{tabular}

CTO, chronic total occlusions; PCI, percutaneous coronary interventions

Follow up started on the date of procedure, ended at the day of death or 1 June 2016. Mean patient observation time was 58.7 months (median 60.1 month).

We did not find significant differences in patient clinical characteristics undergoing antegrade and retrograde, successful and unsuccessful procedures, except regarding prior coronary artery bypass grafting $(\mathrm{CABG})$. In the retrograde approach patient group, $23(13.6 \%)$ had previous CABG, compared to $21(6.0 \%)$ of patients in the antegrade group ( $p=0.004)$. Median (IQR) CTO duration was similar in both retrograde and antegrade groups - 12 (3-60) and 12 (5-36) months, respectively.

Patients with diabetes (insulin dependent and non-insulin dependent) were $21.1 \%(n=74)$ in the antegrade approach

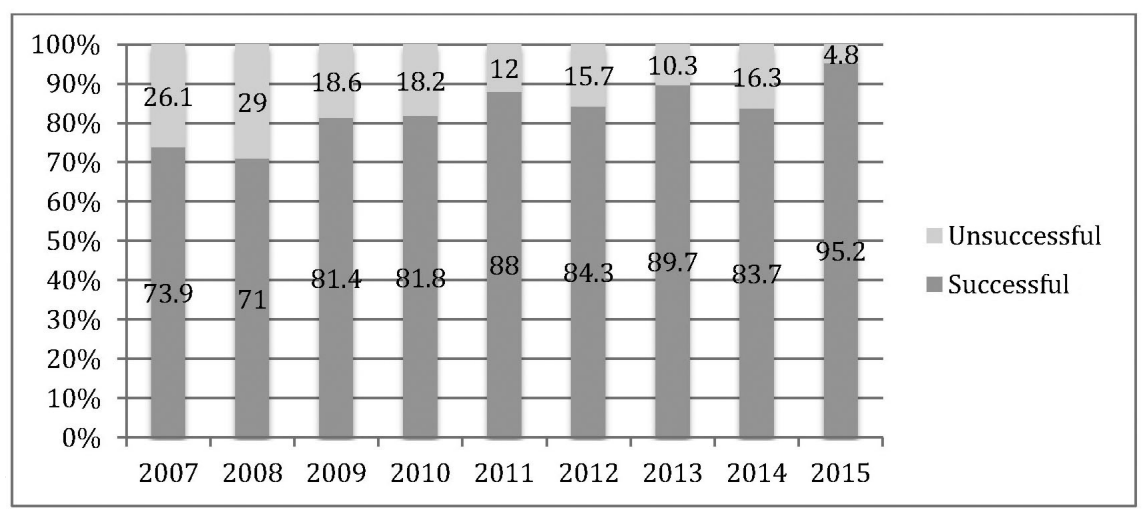

Fig. 2. Overall CTO PCI success rates 2007-2015. CTO, chronic total occlusions; PCI, percutaneous coronary interventions group and $15.4 \%(\mathrm{n}=26)$ in the retrograde approach group $(p=\mathrm{NS})$.

The J-CTO score was calculated for all patients: 215 (41.4\%) had J CTO score 0 and $263(50.7 \%)$ had score 2-3, and $41(7.9 \%)$ of patients had score $4-5$. A retrograde approach was used more frequently in complex cases. For less complex CTO lesions (J-CTO score 0-1), a retrograde approach was used in $7.7 \%$ and $19.7 \%$ of cases, respectively, for intermediate complex lesions (J-CTO score 2 and 3 ) in $30.3 \%$ and $52.9 \%$, respectively, for very complex lesions (J-CTO score 4$)$ in $70.1 \%$ of cases $(p<0.001)$.

Septal collaterals were more frequently used as the retrograde access route $(85.3 \%)$, but during the last two years use of epicardial channels has increased.

The main reasons for failure in both groups (antegrade and retrograde) was inability to cross the occlusion with a wire ( $68.7 \%$ of all unsuccessful cases).

The total complication rate was $6.5 \%: 5.9 \%$ in the antegrade patients group and $7.2 \%(p=0.630)$ in the retrograde group.

Kaplan-Meier curves showed better overall survival in the successful procedure group compared to the unsuccessful group (Long-rank test, p = 0.013) (Fig. 3), but the method used (antegrade or retrograde) did not have any effect on survival (Fig. 4). In the retrograde procedure group, survival was significantly better $(p=0.019)$ if the procedure was successful. Similarly, there was a tendency of better survival in the case of success also among patients who underwent an antegrade procedure, albeit it was not statistically significant ( $p=0.118$ ) (Figs. 5-6). 
CTO PCI PATIENT CHARACTERISTICS ACCORDING TO PROCEDURAL SUCCESS

\begin{tabular}{l|c|c|c}
\hline & $\begin{array}{c}\text { Total } \\
(\mathrm{n}=519)\end{array}$ & $\begin{array}{c}\text { Successful } \\
(\mathrm{n}=422)\end{array}$ & $\begin{array}{c}\text { Unsuccessful } \\
(\mathrm{n}=97)\end{array}$ \\
\hline Mean age $( \pm \mathrm{SD})$ & $63.4(10.5)$ & $63.3(10.7)$ & $64.1(10.0)$ \\
Male, n $(\%)$ & $415(80.0 \%)$ & $338(80.1 \%)$ & $77(79.4 \%)$ \\
Smokers : & $292(56.3 \%)$ & $231(54.7 \%)$ & $6.501(61.9 \%)$ \\
$\quad$-never & $160(30.8 \%)$ & $134(31.8 \%)$ & $26(26.8 \%)$ \\
$\quad$-current & $67(12.9 \%)$ & $57(13.5 \%)$ & $10(10.3 \%)$ \\
Hypertension & $434(83.6 \%)$ & $356(84.4 \%)$ & $78(80.4 \%)$ \\
Dislipidemia & $358(69.0 \%)$ & $298(70.6 \%)$ & $60(61.9 \%)$ \\
Diabetes & $100(19.3 \%)$ & $86(20.4 \%)$ & $14(14.4 \%)$ \\
Prior MI & $380(73.2 \%)$ & $303(71.8 \%)$ & $0.343(79.4 \%)$ \\
Prior CABG & $44(8.5 \%)$ & $34(8.1 \%)$ & 0.093 \\
Prior PCI & $266(51.3 \%)$ & $205(48.6 \%)$ & 0.181 \\
\hline
\end{tabular}

CTO, chronic total occlusions; PCI, percutaneous coronary interventions; $1 \mathrm{MI}$, myocardial infarction; CABG, coronary artery bypass grafting

Retrograde approach

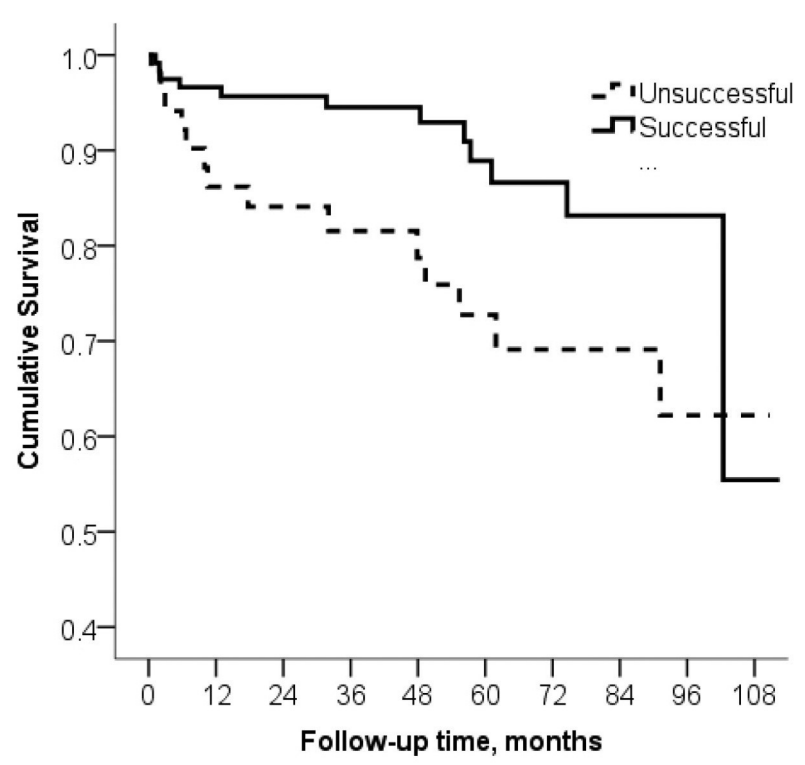

Fig. 3. Survival after successful and unsuccessful CTO PCI retrograde cases. CTO, chronic total occlusions; PCI, percutaneous coronary interventions

Success was associated with lower mortality (Cox regression: HR 0.59 (95\%CI 0.39-0.90; $p=0.014)$. The success of the procedure remained significant also after adjustment for patient age, sex and method: HR 0.58 (95\% CI $0.38-0.89 ; \quad p=0.012$ ).

\section{DISCUSSION}

The true prevalence of a CTO in the general population is unknown and not well studied. In a few older studies the prevalence of CTO in patients undergoing coronary angiography ranged between $10 \%$ and $52 \%$ depending on the clinical profile of the patient being examined. Among patients who underwent coronary angiography because of sus-

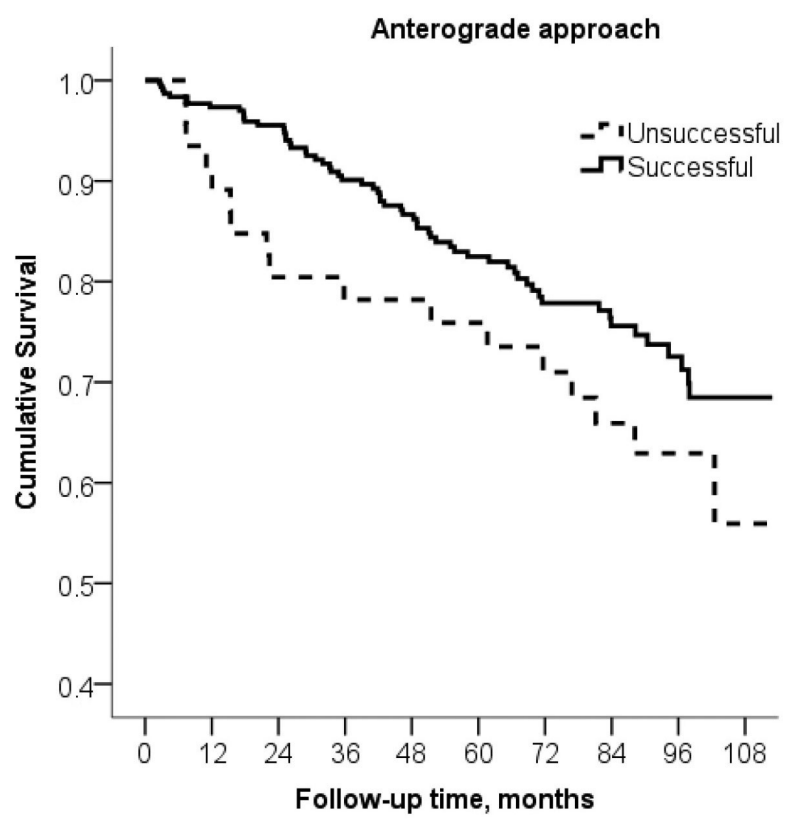

Fig. 4. Survival after successful and unsuccessful CTO PCI antegrade cases. CTO, chronic total occlusions; PCI, percutaneous coronary interventions

pected coronary artery disease, CTO prevalence was $18 \%$, but in patients with angiographically significant coronary artery disease it was 30\% (Christofferson, 2005). CTO prevalence was observed to be higher (54\%) among patients with a history of aortocoronary bypass graft (CABG) surgery and lower (10\%) among patients with acute coronary syndrome undergoing primary PCI (Fefer, 2012).

Data from registries reveal striking variability between different centres and countries. For example, in Japanese centres CTO incidence was $19 \%$ and $61.2 \%$ of these cases were treated percutaneously (Yamamoto et al., 2013), however in North America, where CTOs are more frequent (29-33\%), only between $6 \%$ and $9 \%$ of patients were treated percutaneously (Srinivas et al., 2002). 


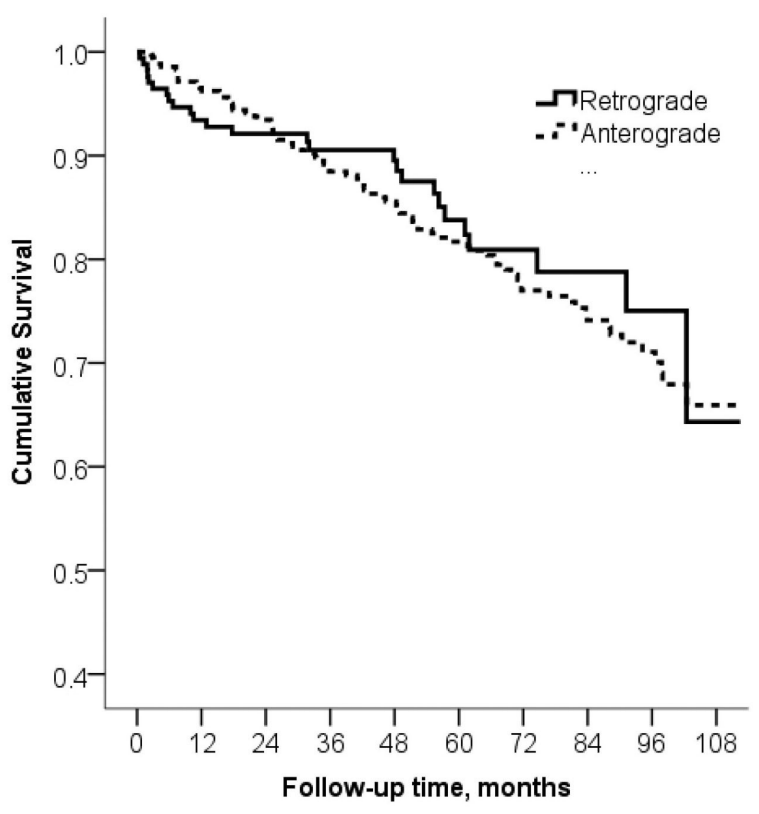

Fig. 5. Overall survival after CTO PCI antegrade and retrograde cases. CTO, chronic total occlusions; PCI, percutaneous coronary interventions

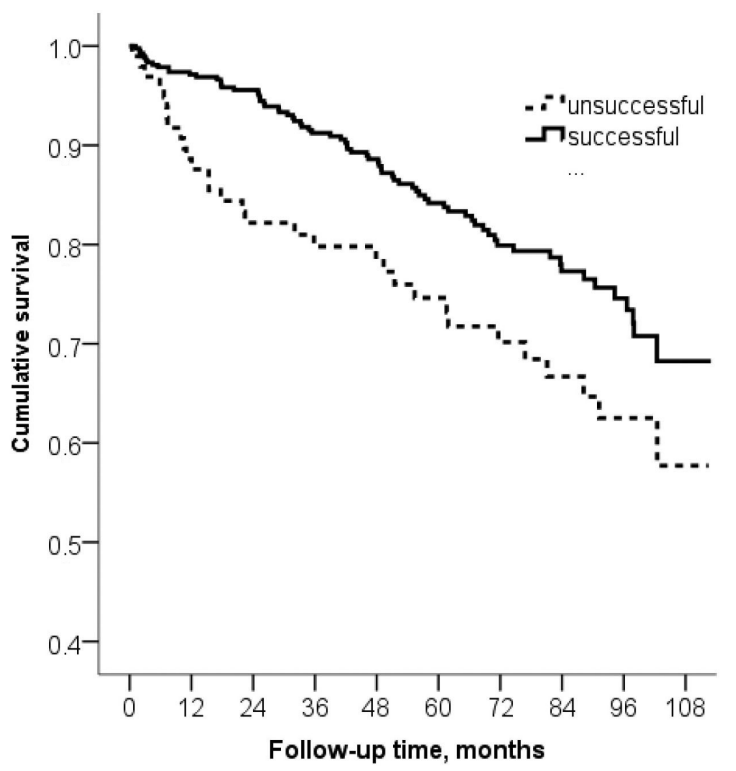

Fig. 6. Overall survival after successful and unsuccessful CTO PCI cases. CTO, chronic total occlusions; PCI, percutaneous coronary interventions

In our study the percentage of CTO PCI procedures was low - only $6.2 \%$ of all PCI. The number of CTO PCI procedures has decreased during the last years, mainly due to more careful patient selection.

According to definition, CTOs are at least three month old lesions. They are therefore always found in stable chronic patients, with varying levels of symptoms. Patients with acute coronary syndrome occasionally also have a CTO in another, non culprit artery, and is therefore considered a CTO.

Several studies showed that CTO patients are a high-risk population with more traditional cardiovascular risk factors, multivessel disease, history of MI and PCI (Fefer et al., 2012; Grantham et al., 2009).

There is no doubt that treatment of CTO affecting an ischemic myocardial area that causes symptoms, such as angina, should improve patient symptoms by providing a greater perfusion flow than that provided by collateral circulation, as a consequence of opening the occluded artery (Werner et al., 2006). In the FACTOR Trial (Flow Cardia Approach to CTO Recanalization), 125 patients completed the Seattle Angina Questionnaire at baseline and one month after percutaneous coronary intervention (Grantham et al., 2010). Successful CTO treatment in this trial was associated with an improvement in the frequency of angina, physical capacity and quality of life. However, this improvement was only observed in previously symptomatic patients but not in asymptomatic patients.

If a patient has angina (and therefore ischemia), the benefit of CTO treatment is symptom relief. For patients without angina, but with ischemia, the benefit is not symptomatic and can be evaluated only in prognostic terms (Aziz et al., 2007). There is not much evidence about the benefit of CTO invasive treatment for non symptomatic patients. The SWISSI II trail conducted in the late 1990s included asymptomatic CTO patients with 1 or 2 coronary artery disease after myocardial infarction and inducible ischemia in an imaging test. The results showed significant reduction of coronary events in the successful CTO PCI group during long-term follow up (Erne et al., 2007).

The recent Clinical Outcomes Utilizing Revascularization and Aggressive Drug Evaluation (COURAGE) trial, which compared PCI with optimal medical therapy in stable coronary disease, did not show a significant difference in mortality or myocardial infarction between the two treatment options. However, CTOs were not included in the COURAGE trial (Boden et al., 2007).

Some older registries have reported that patients with complete revascularisation have a better prognosis than those with incomplete revascularisation, including the presence of an untreated CTO (Hannan et al., 2006, Valenti et al., 2008). The SCAAR (Swedish Coronary Angiography and Angioplasty) Registry includes data from 2006 and 2010 on 23342 patients with multivessel disease. Incomplete revascularisation (IR) was defined as any non-treated significant $(60 \%)$ stenosis in a coronary artery supplying $10 \%$ of the myocardium. IR at the time of hospital discharge in patients with multivessel disease undergoing PCI was associated with a high risk of recurrent 1-year adverse cardiac events (Hambraeus et al., 2016).

Although CTO patients are common in clinical work, the evidence for the current guidelines and clinical practice is limited. According to the current European Society of Cardiology (ESC) Revascularisation guidelines, CTO percutaneous revascularisation is considered in patients with myocardial ischemia given myocardial segment and / or symptoms associated with angina (II A, Class B level rec- 
CTO ANGIOGRAPHIC CHARACTERISTICS

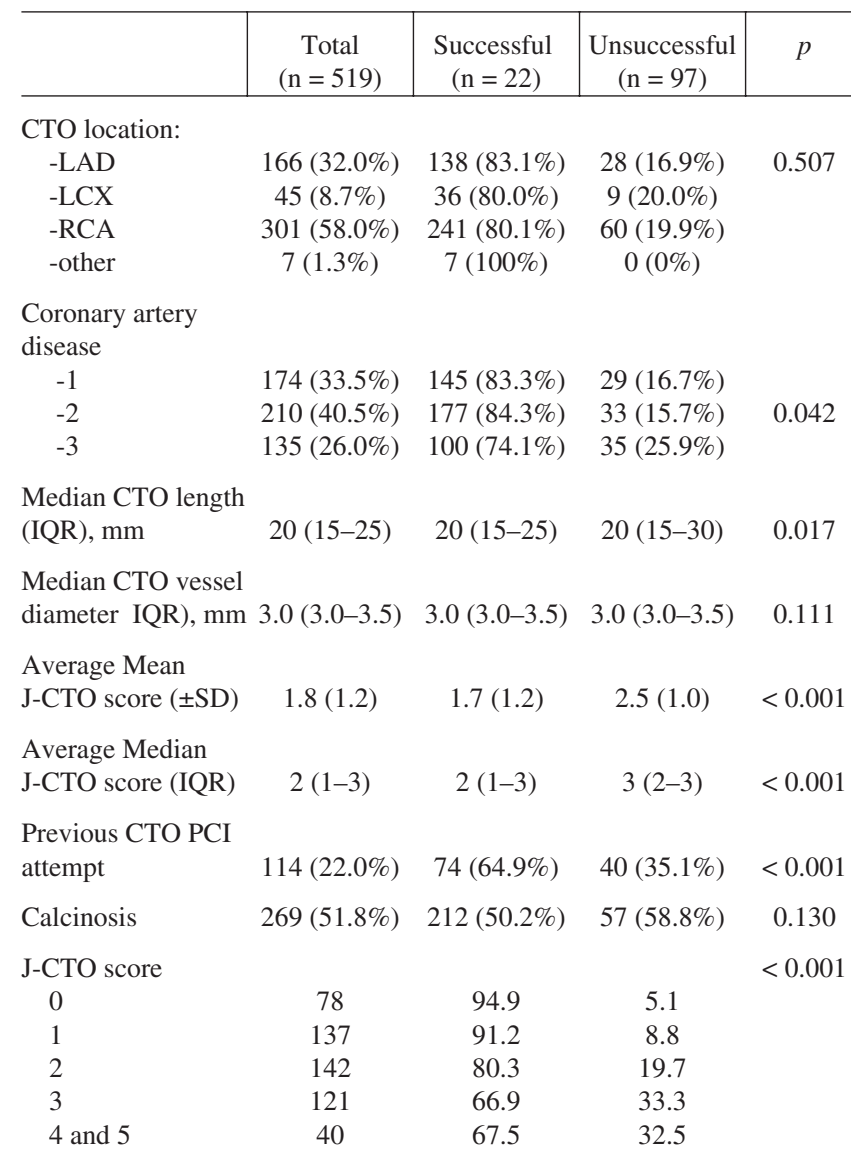

CTO, chronic total occlusions; PCI, percutaneous coronary interventions; $\mathrm{IQR}$, interquartile range;

ommendation) (Kolh et al., 2014). A Retrograde approach is recommended as a class $\mathrm{IIb}$ recommendation level $\mathrm{C}$, after an unsuccessful antegrade approach or as a starting method for selected patients, without describing this patient group (Kolh et al., 2014).

In our study indication for CTO PCI was at least one of the following: symptoms (angina), positive exercise test, ischemia. We also performed PCI for asymptomatic CTO patients after myocardial infarction in a non-CTO area with normal ECG and normal echo findings in the CTO-related area. Of course, this does not fully comply with modern understanding about myocardial viability and ischemia, but for several reasons modern myocardial viability examinations in our hospital were not available until 2013 and the main examination given for these patients was an exercise test. Due to better patient selection the number of CTO PCI procedures in our hospital has decreased.

Until 2005, the success rates of operators experienced in conventional CTO percutaneous coronary intervention (PCI) techniques has remained unchanged (60-70\%), which is considerably lower than the success rates in nonocclusive coronary artery disease (Ivanhoe et al., 1992). Many techniques and devices (wires, microcatheters) have
COMPLICATIONS IN ANTEGRADE AND RETROGRADE CTO PCI PATIENTS

\begin{tabular}{l|c|c|c|c}
\hline & $\begin{array}{c}\text { Total } \\
(\mathrm{n}=519)\end{array}$ & $\begin{array}{c}\text { Antegrade } \\
(\mathrm{n}=352)\end{array}$ & $\begin{array}{c}\text { Retrograde } \\
(\mathrm{n}=167)\end{array}$ & $p$ \\
\hline Complications & $34(6.5 \%)$ & $21(5.9 \%)$ & $12(7.2 \%)$ & 0.630 \\
& & & & T a b le 5
\end{tabular}

COMPLICATIONS IN SUCCESSFUL AND UNSUCCESSFUL CTO PCI PATIENTS

\begin{tabular}{l|c|c|c|c}
\hline & $\begin{array}{c}\text { Total } \\
(\mathrm{n}=519)\end{array}$ & $\begin{array}{c}\text { Successful } \\
(\mathrm{n}=422)\end{array}$ & $\begin{array}{c}\text { Unsuccessful } \\
(\mathrm{n}=97)\end{array}$ & $p$ \\
\hline Complications & $34(6.5 \%)$ & $23(5.4 \%)$ & $10(10.3 \%)$ & 0.077
\end{tabular}

CTO, chronic total occlusions; PCI, percutaneous coronary interventions

been introduced into clinical practice to improve the effectiveness of CTO revascularisation (Sumitsuji et al., 2011). One of the most important and popular techniques is the retrograde approach, nowadays widely used, and first described in 1990 by Kahn and Hartzler (1990). The first report of retrograde crossing via septal collaterals was published in 2006, starting the modern era, rapidly evolving with the introduction of specialised equipment (Surmely et al., 2006).

Vast experience in CTO invasive treatment has been gained in Japan. According to data from the Japan Retrograde Summit registry (Yoshikawa et al., 2013), use of the retrograde method was $26.6 \%$ of all PCI CTO and rate of success has reached $84.8 \%$.

Slightly lower success rates appear in the Euro CTO Club register, which is world's largest. According to the data from this register, during the period from year 2008 to 2012 , a retrograde method was used in $16.5 \%$ of successful procedures and the success rate reached $75 \%$ (Gallassi et al., 2015).

In our study a retrograde approach was used in $32.2 \%$ of cases with success rate $71 \%$, which is comparable with data from Euro CTO Club registry. Use of a retrograde approach has decreased during the last two years, likely due to operator skill improvement and introduction of new technologies for antegrade CTO crossing.

The goal of CTO PCI has always been to make life easier for patients by reducing symptoms and improving prognosis by reducing the number of major cardiovascular events. Multi-register data shows that successfully undergone CTO PCI improves patient prognosis (Mehran, 2011; Joyal, 2010). In our study, unfortunately, symptom evaluation of patients was not carried out, but, comparing survival after successful and unsuccessful CTO PCI, significantly better results were observed in the successful patient group (Fig. 3 ). These results coincide with data obtained in our hospital in 2013 in a shorter observation period (Kalnins et al., 2013). 


\section{CONCLUSIONS}

The main finding of this study was increased survival in patients with successful CTO opening for symptomatic and/or ischemic patients and patients with CTO, but without previous myocardial infarction. Long-term outcome and survival after CTO PCI not only depends on the approach (antegrade or retrograde), but depends on results of the procedure.

The authors declare that there is no conflict of interests regarding the publication of this paper.

\section{REFERENCES}

Aziz, S., Stables, R. H., Grayson, A. D., Perry, R. A., Ramsdale, D. R. (2007). Percutaneous coronary intervention for chronic total occlusions: Improved survival for patients with successful revascularization compared to a failed procedure. Catheter. Cardiovasc. Interv., 70, 15-20.

Boden, W. E., O’Rourke, R. A., Teo, K. K., Hartigan, P. M., Maron, D. J., Kostuk, W. J., Knudtson, M., Dada, M., Casperson, P., Harris, C. L., Chaitman, B. R., Shaw, L., Gosselin, G., Nawaz, S., Title, L. M., Gau, G., Blaustein, A. S., Booth, D. C., Bates, E. R., Spertus, J. A, Berman, D. S., Mancini, G. B., Weintraub, W. S. (2007). Optimal medical therapy with or without PCI for stable coronary disease. New Engl. J. Med., 356, 1503-1516.

Christofferson, R. D., Lehmann, K. G., Martin, G. V., Every, N., Caldwell, J. H., Kapadia, S. R. (2005). Effect of chronic total coronary occlusion on treatment strategy. Amer. J. Cardiol., 95, 1088-1091.

Erne, P., Schoenenberger, A. W., Burckhardt, D., Zuber, M., Kiowski, W., Buser, P. T., Dubach, P., Resink, T. J., Pfisterer, M. (2007). Effects of percutaneous coronary interventions in silent ischemia after myocardial infarction: The SWISSI II randomized controlled trial. The Journal of the American Medical Association (JAMA), 297, 1985-1991.

Fefer, P., Knudtson, M. L., Cheema, A. N., Galbraith, P. D., Osherov, A. B., Yalonetsky, S., Gannot, S., Samuel, M., Weisbrod, M., Bierstone, D., Sparkes, J. D., Wright, G. A., Strauss, B. H. (2012). Current perspectives on coronary chronic total occlusions: The Canadian Multicenter Chronic Total Occlusions Registry. J. Amer. Coll. Cardiol., 59, 991-997.

Gallassi, A. R., Sianos, G., Werner, G. S., Escaned, J., Tomasello, S. D., Boukhris, M., Castaing, M., Büttner, J. H., Bufe, A., Kalnins, A., Spratt, J. C., Garbo, R., Hildick-Smith, D., Elhadad, S., Gagnor, A., Lauer, B., Bryniarski, L., Christiansen, E. H., Thuesen, L., Meyer-Geßner, M., Goktekin, O., Carlino, M., Louvard, Y., Lefèvre, T., Lismanis, A., Gelev, V. L., Serra, A., Marza, F., Di Mario, C., Reifart, N. (2015). Euro CTO Club. Retrograde recanalization of chronic total occlusions in Europe. $J$. Amer. Coll. Cardiol., 22, 2388-2400.

Grantham, J. A., Marso, S. P., Spertus, J., House, J., Holmes, D. R., Jr., Rutherford, B. D. (2009). Chronic total occlusion angioplasty in the United States. J. Amer. Coll. Cardiol. Cardiovasc. Intervent., 2, 479-486.

Grantham, J. A., Jones, P. G., Cannon, L., Spertus, J. A. (2010). Quantifying the early health status benefits of successful chronic total occlusion recanalization: Results from the FlowCardia's Approach to Chronic Total Occlusion Recanalization (FACTOR) Trial. Circ. Cardiovasc. Qual. Outcomes. 3, 284-290.

Hannan, E. L., Racz, M., Holmes, D. R., King, S. B., Walford, G., Ambrose, J. A., Sharma, S., Katz, S., Clark, L. T., Jones, R. H. (2006). Impact of completeness of percutaneous coronary intervention revascularization on long-term outcomes in the stent era. Circulation, 113 (20), 2406-2412.

Hambraeus, K., Jensevik, K., Lagerqvist, B., Lindahl B, Carlsson R, Farzaneh-Far R, Kellerth, T., Omerovic, E., Stone, G., Varenhorst, C., James, S. (2016). Long-Term Outcome of Incomplete Revascularization After Percutaneous Coronary Intervention in SCAAR (Swedish Coronary
Angiography and Angioplasty Registry). J. Amer. Coll. Cardiol. Intv., 9 (3), 207-215.

Hoye, A., van Domburg, R. T., Sonnenschein, K., Serruys, P. W. (2005). Percutaneous coronary intervention for chronic total occlusions: The Thoraxcenter experience 1992-2002. Eur. Heart J., 26, 2630-2636.

Ivanhoe, R. J., Weintraub, W. S., Douglas, J. S. Jr., Lembo, N. J., Furman, M., Gershony, G., Cohen, C. L., King, S. B. 3rd. (1992). Percutaneous transluminal coronary angioplasty of chronic total occlusions. Primary success, restenosis, and long term clinical follow up. Circulation, $\mathbf{8 5}$, $106-115$.

Joyal, D., Bertrand, O. F., Rinfret, S., Shimony, A., Eisenberg, M. J. (2012). Meta-analysis often trials on the effectiveness of the radial versus the femoral approach in primary percutaneous coronary intervention. Amer. J. Cardiol., 109, 813-818.

Joyal, D., Afilalo, J., Rinfret, S. (2010). Effectiveness of recanalization of chronic total occlusions: A systematic review and meta-analysis. Amer. Heart J., 160, 179-187.

Kahn, J. K., Hartzler, G. O. (1990). Retrograde coronary angioplasty of isolated arterial segments through saphenous vein bypass grafts. Cathet. Cardiovasc. Diagn., 20 (2), 88-93.

Kalnins, A., Strele, I., Lejnieks, A., Lukstins, G. (2013). Chronic total coronary artery occlusion recanalization with percutaneous coronary intervention using anterograde and retrograde approach - Riga EAST Clinical University Hospital Experience. Acta Chirurgica Latviensis, 13 (1), 17-21.

Kolh, P., Windecker, S., Alfonso, F., Collet, J. P., Cremer, J., Falk, V., Filippatos, G., Hamm, C., Head, S. J., Jüni, P., Kappetein, A. P., Kastrati, A., Knuuti, J., Landmesser, U., Laufer, G., Neumann, F. J., Richter, D. J., Schauerte, P., Sousa Uva, M., Stefanini, G. G., Taggart, D. P., Torracca, L., Valgimigli, M., Wijns, W., Witkowski, A., Zamorano, J. L., Achenbach, S., Baumgartner, H., Bax, J. J., Bueno, H., Dean, V., Deaton, C., Erol, Ē., Fagard, R., Ferrari, R., Hasdai, D., Hoes, A. W., Kirchhof, P., Knuuti, J., Kolh, P., Lancellotti, P., Linhart, A., Nihoyannopoulos, P., Piepoli, M. F., Ponikowski, P., Sirnes, P. A., Tamargo, J. L., Tendera, M., Torbicki, A., Wijns, W., Windecker, S., Pepper, J., Anyanwu, A., Badimon, L., Bauersachs, J., Baumbach, A., Beygui, F., Bonaros, N., De Carlo, M., Dobrev, D., Dunning, J., Eeckhout, E., Gielen, S., Hasdai, D., Kirchhof, P., Luckraz, H., Mahrholdt, H., Montalescot, G., Paparella, D., Rastan, A. J., Sanmartin, M., Sergeant, P., Silber, S., Tamargo, J., ten Berg, J., Thiele, H., van Geuns, R. J., Wagner, H. O., Wassmann, S., Wendler, O., (2014). 2014 ESC/EACTS Guidelines on myocardial revascularization: The Task Force on Myocardial Revascularization of the European Society of Cardiology (ESC) and the European Association for Cardio-Thoracic Surgery (EACTS). Eur. J. Cardiothorac. Surg., 46 (4), 517-592.

Mehran, R., Claessen, B. E., Godino, C., Dangas, G. D., Obunai, K., Kanwal, S., Carlino, M., Henriques, J. P., Di Mario, C., Kim, Y. H., Park, S. J., Stone, G. W., Leon, M. B., Moses, J. W., Colombo, A. (2011). Long-term outcome of percutaneous coronary intervention for chronic total occlusions. J. Amer. Coll. Cardiol. Interv., 4, 952-961.

Prasad, A., Rihal, C. S., Lennon, R. J., Wiste, H. J., Singh, M., Holmes, D. R. Jr. (2007). Trends in outcomes after percutaneous coronary intervention for chronic total occlusions: A 25-year experience from the Mayo Clinic. $J$. Amer. Coll. Cardiol., 49, 1611-1618.

Shah, P. B. (2011). Management of coronary chronic total occlusion. Circulation, 123, 1780-1784.

Saito, S. (2008). Different strategies of retrograde approach in coronary angioplasty for chronic total occlusion. Catheter. Cardiovasc. Interv., 71, 8-19.

Srinivas, V. S., Brooks, M. M., Detre, K. M., King, S. B., Jacobs, A. K., Johnston, J., Williams, D. O. (2002). Contemporary percutaneous coronary intervention versus balloon angioplasty for multivessel coronary artery disease: A comparison of the National Heart, Lung and Blood Institute Dynamic Registry and the Bypass Angioplasty Revascularization Investigation (BARI) study. Circulation, 106, 1627-1633. 
Suero, J. A., Marso, S. P., Jones, P. G., Laster, S. B., Huber, K. C., Giorgi, L. V., Johnson, W. L., Rutherford, B. D. (2001). Procedural outcomes and long-term survival among patients undergoing percutaneous coronary intervention of a chronic total occlusion in native coronary arteries: A 20-year experience. J. Amer. Coll. Cardiol., 38, 409-414.

Sumitsuji, S., Inoue, K., Ochiai, M., Tsuchikane, E., Ikeno, F. (2011). Fundamental wire technique and current standard strategy of percutaneous intervention for chronic total occlusion with histopathological insights. Cardiovasc. Interv., 4 (9), 941-951.

Surmely, J. F., Tsuchikane, E., Katoh, O., Nishida, Y., Nakayama, M., Nakamura, S., Oida, A., Hattori, E., Suzuki, T. (2006). New concept for CTO recanalization using controlled antegrade and retrograde subintimal tracking: The CART technique, J. Invasive Cardiol., 18 (7), 334-338.

Valenti, R., Migliorini, A., Signorini, U., Vergara, R., Parodi, G., Carrabba, N., Cerisano, G., Antoniucci, D. (2008). Impact of complete revascularization with percutaneous coronary interventionon survival in patients with at least one chronic totalocclusion. Eur. Heart. J., 29 (19), 2336-2342.

Yoshikawa, R., Tsuchikane, E., Muramatsu, T., Nakamura, S., Okamura, A., Igarashi Y., Matsubara, T., Fujita, T., Muto, M., Yamane, M. (2013). Multicenter registry data in Japan for retrograde PCI of chronic total occlu- sion during the past three years: Have new devices and techniques changed the strategies of retrograde approach? J. Amer. Coll. Cardiol., 61 (10). doi:10.1016/S0735-1097(13)61690-3.

Yamamoto, E., Natsuaki, M., Morimoto, T., Furukawa, Y., Nakagawa, Y., Ono, K., Mitsudo, K., Nobuyoshi, M., Doi, O., Tamura, T., Tanaka, M., Kimura, T. (2013). Long-term outcomes after percutaneous coronary intervention for chronic total occlusion(from the CREDO-Kyoto registry cohort-2). Amer. J. Cardiol. 112, 767-774.

Werner, G. S., Gitt, A. K., Zeymer, U., Juenger, C., Towae, F., Wienbergen, H., Senges, J. (2009). Chronic total coronary occlusions in patients with stable angina pectoris: Impact on therapy and outcome in present day clinical practice. Clin. Res. Cardiol., 98 (7), 435-441.

Werner, G. S., Surber, R., Kuethe, F., Emig, U., Schwarz, G., Bahrmann, P., Figulla, H. R. (2005). Collaterals and the recovery of left ventricular function after recanalizationof a chronic total coronary occlusion. Amer. Heart. J., 149 (1), 129-137.

Werner, G. S., Surber, R., Ferrari, M., Fritzenwanger, M., Figulla, H. R. (2006). The functional reserve of collaterals supplying long-term chronic total coronary occlusions in patients without prior myocardial infarction. Eur. Heart. J., 27 (20), 2406-2412.

Received 22 September 2016

Accepted in the final form 2 May 2017

\section{HRONISKU TOTĀLU KORONĀRO ARTĒRIJU OKLŪZIJU REKANALIZĀCIJA, PIELIETOJOT PERKUTĀNO KORONĀRO INTERVENCI — VIENA CENTRA 10 GADU PIEREDZE}

Hroniskas totālas koronāro artēriju oklūzijas (HTO) sastopamas vienai trešdaḷai pacientu ar nozīmīgu koronāro sirds slimību. HTO invazīva ārstēšana ir apgrūtināta tās sarežǵìtības dēḷ. Pielietojot tradicionālo anterogrādo metodi, sekmīgo procedūru skaits nepārsniedz 60-70\%. Rezultātus iespējams ievērojami uzlabot, lietojot jaunākās retrogrādās HTO rekanalizācijas metodes. Pētījuma mērḳis bija izanalizēt vienas terciārā līmeņa slimnīcas desmit gadu pieredzi HTO invazīvā ārstēšanā un izvērtēt ilgtermiņa rezultātus. Pētījumā tika iekḷauti 519 pacienti. To vidējais vecums bija 64 gadi, un 80\% no tiem bija vīrieši. Retrogrādā rekanalizācijas metode tika pielietota 167 (32,2\%) pacientiem. Sekmīgo procedūra skaits pieaudzis no 73,9\% 2007. gadā līdz 95,2\% 2015. gadā. Vidējais pacientu novērošanas laiks bija 4,5 gadi. Statistiski labāka dzīvildze tika novērota sekmīgi veikto procedūru pacientu grupā (Long-rank test, $p=0,013)$. 